\title{
Identifikasi Keragaman Gen DGAT1 serta Asosiasinya terhadap Karakteristik Karkas dan Sifat Perlemakan Domba
}

\author{
Asep Gunawan ${ }^{1 *}$, Ratna Sholatia Harahap ${ }^{1}$, Kasita Listyarini ${ }^{1}$, Cece Sumantri ${ }^{1}$ \\ ${ }^{1}$ Departemen Ilmu Produksi dan Teknologi Peternakan, Fakultas Peternakan IPB \\ Jl. Agatis Kampus IPB Dramaga, Bogor 16680 \\ *Email korespondensi: aagun4780@gmail.com
}

(Diterima: 25-03-2019; disetujui 26-04-2019)

\begin{abstract}
ABSTRAK
Karakteristik karkas dan sifat perlemakan pada daging domba dikontrol oleh banyak gen salah satunya gen DGAT1 (Diacylglycerol Acyltransferasel 1). Penelitian ini bertujuan mengidentifikasi SNP (Single Nucleotide Polymorphism) gen DGAT1 pada titik mutasi g.8539 C >T dan asosiasinya terhadap karakteristik karkas dan sifat perlemakan pada domba Indonesia. Total sampel domba yang digunakan sebanyak 150 buah terdiri dari 35 sampel domba compass agrinak (DCA), 36 sampel domba barbados cross (DBC), 41 sampel domba komposit garut (DKG), 20 sampel domba ekor gemuk (DEG), dan 18 sampel domba ekor tipis (DET). Karakteristik karkas dan sifat perlemakan diukur dari domba jantan berumur 10-12 bulan. Identifikasi keragaman DGAT1|ALuI dianalisis dengan metode PCR-RFLP (Polymerase Chain Reaction-Restriction Fragment Length Polymorphism). Hasil keragaman gen DGAT1 bersifat polimorfik dalam DET dan DEG, sedangkan DCA, DBC, dan DKG bersifat monomorfik. Dua genotipe disebut CC dan CT ditemukan dalam DET dan DEG. Titik mutasi gen DGAT1 berasosiasi $(\mathrm{P}<0.05)$ dengan karakteristik karkas, yaitu bobot dan panjang karkas. Selain itu, keragaman gen DGAT1 juga berasosiasi signifikan $(\mathrm{P}<0.05)$ dengan asam lemak jenuh, yaitu asam stearat (C18:0) dan asam arakidat (C20:0) dan asam lemak tak jenuh tunggal, yaitu asam oleat (C18:1n9c). Gen DGAT1 memiliki kontribusi dalam karakteristik karkas dan komposisi asam lemak pada domba.
\end{abstract}

Kata Kunci: domba, gen DGAT1, karakteristik karkas, PCR-RFLP, sifat perlemakan

\begin{abstract}
Characteristic of carcass and fatness traits of sheep is regulated by many genes such as DGAT1 (Diacylglycerol Acyltransferasel 1) gene. The research was aimed to investigate SNP (Single Nucleotide Polymorphism) of DGAT1 and its association with characteristic of carcass and fatness traits in Indonesian sheep. A total sample of sheeps used 150 rams of 10-12 months consisted 35 samples of compas agrinak sheep (CAS), 36 of barbados cross (BCS), 41 of garut composite (GCS), 20 of javanese fat tailed (JFT), and 18 of javanese thin tailed (JTT). Identification variant of DGAT1|ALuI were performed by PCR-RFLP (Polymerase Chain Reaction-Restriction Fragment Length Polymorphism). The results of polymorphism of DGAT1 were found in JTT and JFT. However, SNP of DGAT1 in CAS, BCS and GCS were monomorfic. Two genotype namely CC and CT were found in JTT and JFT populations. A SNP of the DGAT1 was associated $(\mathrm{P}<0.05)$ with characteristic of carcass, including weight and length of carcass. The variant of DGAT1 was associated too with saturated fatty acids (SFA) including stearic acid (C18:0) and arachidic acid (C20:0), and mono unsaturated fatty acid (MUFA) including oleic acid $(\mathrm{C} 18: 1 \mathrm{n} 9 \mathrm{c})$. The DGAT1 gene was contribute to characteristic carcass and fatty acid composition in sheep.
\end{abstract}

Keywords: DGAT1 gene, characteristic carcass, fatness traits, PCR-RFLP, sheep 


\section{PENDAHULUAN}

Konsumsi daging Nasional semakin meningkat tiap tahunnya. Menurut Organisation for Economic Co-operation and Development (2018) konsumsi daging domba di Indonesia mengalami peningkatan dari tahun $2017 \mathrm{ke}$ 2018, yaitu sebesar $0,359 \mathrm{~kg} \mathrm{kapita}^{-1}$ menjadi $0,366 \mathrm{~kg} \mathrm{kapita}^{-1}$. Akan tetapi, kontribusi daging domba dalam pemenuhan kebutuhan daging nasional masih rendah dibanding lainnya, yaitu sebesar 2\% dibanding daging sapi sebesar $16 \%$ (DPKH 2017). Faktor-faktor yang diduga menjadi penyebab rendahnya konsumsi daging domba secara Nasional diantaranya adanya persepsi di masyarakat bahwa daging domba memiiki tingkat off flavour dan odor tinggi atau bau daging yang kurang diminati dan sulit untuk dihilangkan (Gunawan et al., 2019; Gunawan et al, 2018a; Listyarini et al, 2018), mengandung kolesterol dan kandungan asam lemak jenuh tinggi (Gunawan et al., 2019 ; Gunawan et al., 2018 ; Hidayati 2015).

Rendahnya minat konsumsi daging domba perlu didorong upaya lain melalui peningkatan kualitas daging domba yang berkualitas sesuai dengan preferensi konsumen diantaranya melalui perbaikkan sifat karakteristik karkas dan sifat perlemakan daging domba. Karakteristik karkas dan sifat perlemakan merupakan sifat yang bernilai ekonomis, dikontrol oleh banyak gen, dan secara posisi terletak di beberapa kromosom yang strategis berdasarkan Quantitative Trait Loci (QTL) (Grisart et al., 2002). Kualitas daging berkorelasi positif dengan lemak baik pada karkas maupun daging (Taniguchi et al,. 2004). Selain itu, sifat perlemakan yang terdiri dari konten lemak dan komposisi asam lemak perlu diarahkan terhadap asam lemak tak jenuh yang tinggi dan rendah kolesterol yang berasosiasi positif terhadap kesehatan (Gunawan et al, 2018b). Konsumsi daging yang mengandung asam lemak jenuh tinggi dapat menyebabkan peningkatan kolesterol plasma yang berimplikasi pada penyakit beberapa penyakit diantaranya kardiovaskuler (Alvarenga et al., 2015). Tingginya nilai heritabilitas komposisi asam lemak berkisar 0,60-0,63 (Inounu et al., 2017) menandakan bahwa seleksi gen pengontrol karakteristik karkas dan sifat perlemakan akan efektif meningkatkan mutu genetik daging daging domba.

Salah satu upaya yang dapat dilakukan untuk menghasilkan daging domba dengan mutu genetik yang tinggi, yaitu seleksi berbasis molekuler melalui identifikasi gen pengontrol asam lemak pada domba. Diacylglycerol Acyltransferasel 1 (DGAT1) merupakan salah satu gen yang berperan penting terhadap metabolisme lemak. Gen ini terletak pada membran retikulum endoplasma yang merupakan satu-satunya protein spesifik untuk sintesis triasilgliserol. Gen DGAT1 mengkodekan enzim katalis dari reaksi antara diacylgliserol dan acyl-CoA. Reaksi ini merupakan proses akhir dalam sintesis trigliserida (Casses et al., 1998). Secara genetik, trigliserida merupakan komposisi utama penyusun marbling. Gen DGAT1 pada domba terletak pada kromosom 9 dan merupakan salah satu dari gen kandidat yang berpengaruh terhadap penciri kualitas daging domba.

Beberapa penelitian terkait keragaman dan asosiasi gen DGAT1 telah dilakukan. Keragaman titik mutasi pada ekson 16-17 (DGAT1|AluI) dilaporkan berasosiasi dengan karakteristik karkas pada domba Iran (Mohammadi et al., 2013). Gen DGAT1 juga dilaporkan berasosiasi dengan lemak intramuskular dan keempukan pada domba China (Xu et al., 2009). Identifikasi keragaman gen DGAT1 pada ternak lain seperti sapi asli Indonesia yaitu sapi Bali telah dilaporkan oleh Alwiyah (2016). Namun informasi keragaman gen DGAT1 sebagai salah satu gen pengontrol asam lemak dan karakteristik karkas pada ternak domba khususnya domba Indonesia belum banyak dilakukan. Penelitian ini bertujuan untuk mengidentifikasi keragaman gen DGAT1 serta kaitannya terhadap karakteristik karkas dan sifat perlemakan pada domba Indonesia.

\section{MATERI DAN METODE}

\section{Ternak dan Sampel Penelitian}

Ternak domba yang digunakan dalam penelitian ini terdiri dari 5 jenis domba yaitu domba compass agrinak (DCA), domba barbados cross (DBC), domba komposit garut (DKG), domba ekor tipis (DET), dan domba ekor gemuk (DEG) yang berumur 10-12 bulan 
dengan jenis kelamin jantan. Domba dipelihara secara intensif di Pusat Penelitian Ternak (Puslitnak) Bogor dan diberikan pakan secara $a d$ libitum yang terdiri atas rumput gajah dan konsentrat. Total sampel domba yang digunakan sebanyak 150 ekor yang terdiri dari 35 sampel DCA, 36 sampel DBC, 41 sampel DKG, 20 sampel DEG, dan 18 sampel DET. Karakteristik karkas yang diukur berasal dari 53 ekor domba yang masing-masing terdiri dari DCA $(n=10)$, DBC $(n=10)$, DKG $(n=10)$, DEG $(n=20)$, dan DET $(n=3)$. Sifat perlemakan yang diuji berasal dari 68 ekor domba yang terdiri dari DCA $(n=10)$, DBC $(n=10)$, DKG $(n=10)$, DEG $(n=20)$, dan DET $(n=18)$.

\section{Analisis Sifat Perlemakan: Konten Lemak dan Komposisi Asam Lemak}

Analisis konten lemak menggunakan metode ekstraksi yang mengacu pada Folch et al., 1957), sedangkan analisis komposisi asam lemak menggunakan metode Gas Kromatografi (AOAC 2012). Sampel yang dianalisis berasal dari daging domba bagian loin sebanyak $500 \mathrm{~g}$. Peubah yang diukur meliputi konten lemak, asam lemak jenuh (SFA), asam lemak tak jenuh tunggal (MUFA), asam lemak tak jenuh ganda (PUFA), dan kandungan total asam lemak.

\section{Purifikasi DNA dan Amplifikasi PCR- RFLP|ALUI}

DNA diekstraksi dari darah dan jaringan loin. Prosedur ekstraksi DNA mengacu pada Sambrook dan Russel (2001). Titik mutasi gen DGAT1 yang digunakan hasil modifikasi dari $\mathrm{Xu}$ et al. (2008). Primer gen yang digunakan untuk mengamplifikasi DNA target sepanjang 466 bp (base pare) adalah F: 5'-CCT CTG CCT TCT TCC ATG AG-'3 dan R: 5'-CAG TAC AGC AGC AAG TGG TG-'3 didesain menggunakan program MEGA 6.0. Proses amplifikasi dimulai dengan tahapan denaturasi awal pada suhu $95^{\circ} \mathrm{C}$ selama 5 menit. Tahapan kedua sebanyak 35 siklus yang masing-masing terdiri dari tahap denaturasi $95{ }^{\circ} \mathrm{C}$ selama 10 detik, annealing primer pada suhu $58{ }^{\circ} \mathrm{C}$ selama 20 detik, dan ekstensi DNA pada $72{ }^{\circ} \mathrm{C}$ selama 30 detik. Tahapan terakhir, yaitu pemanjangan primer pada suhu $72{ }^{\circ} \mathrm{C}$ selama 5 menit. Produk PCR dielektroforesis menggunakan media gel agarosa $1.5 \%$ lalu divisualisasikan menggunakan mesin thermocycler dengan bantuan UV Transiluminator untuk melihat pita DNA. Produk PCR kemudian dipotong menggunakan teknik PCR-RFLP dengan enzim AluI dengan cara diinkubasi pada suhu $37^{\circ} \mathrm{C}$ selama 6 jam. Hasil pemotongan kemudian dielektroforesis kembali menggunakan gel agarosa $2.5 \%$ lalu divisualisasikan untuk melihat genotipe yang dihasilkan $(\mathrm{CC}=466 \mathrm{bp}$; TT $=390,76 \mathrm{bp} ; \mathrm{CT}=$ 466,390, dan 76 bp).

\section{Analisis Data}

Hubungan antara genotipe gen DGAT1 terhadap karakteristik karkas dan sifat perlemakan dilakukan menggunakan Uji $\mathrm{T}$ dengan software Minitab. Model matematika yang digunakan sebagai berikut (Walpole, 1995).

$$
t=\frac{\left(X_{1}-X_{2}\right)}{\delta^{2} \frac{\sqrt{1}}{n_{1}}+\delta^{2} \frac{\sqrt{1}}{n_{2}}} \delta^{2}
$$

Keterangan: $\mathrm{X} 1$ dan $\mathrm{X} 2=$ rataan karakteristik karkas atau sifat perlemakan dari genotipe 1 dan 2 ; $\mathrm{n} 1$ dan $\mathrm{n} 2=$ jumlah individu genotipe 1 dan $2 ; \delta 2=$ ragam gabungan.

\section{HASIL DAN PEMBAHASAN}

\section{SNP Gen DGAT1}

Produk PCR dengan panjang 466 bp berhasil diamplifikasi seperti pada Gambar 1. Terjadi perubahan basa Cytosin (C) menjadi basa Timin (T) pada exon 17 di titik mutasi 8539. Dua genotipe yang teridentifikasi setelah proses pemotongan, yaitu CC (466 bp) dan CT (466, 390) yang merupakan kombinasi dari alel $\mathrm{C}$ dan $\mathrm{T}$. Hasil PCR-RFLP gen DGAT1 disajikan pada Gambar 2. Metode PCR-RFLP dilakukan sebagai analisis lanjutan dari produk PCR untuk mengetahui keragaman dalam suatu populasi (Muladno 2009). Enzim restriksi yang digunakan AluI memiliki situs pemotong AGC|T. Enzim restriksi dapat memotong molekul urutan spesifik DNA dengan ukuran fragmen yang berbeda-beda (Klug et al., 2006). 


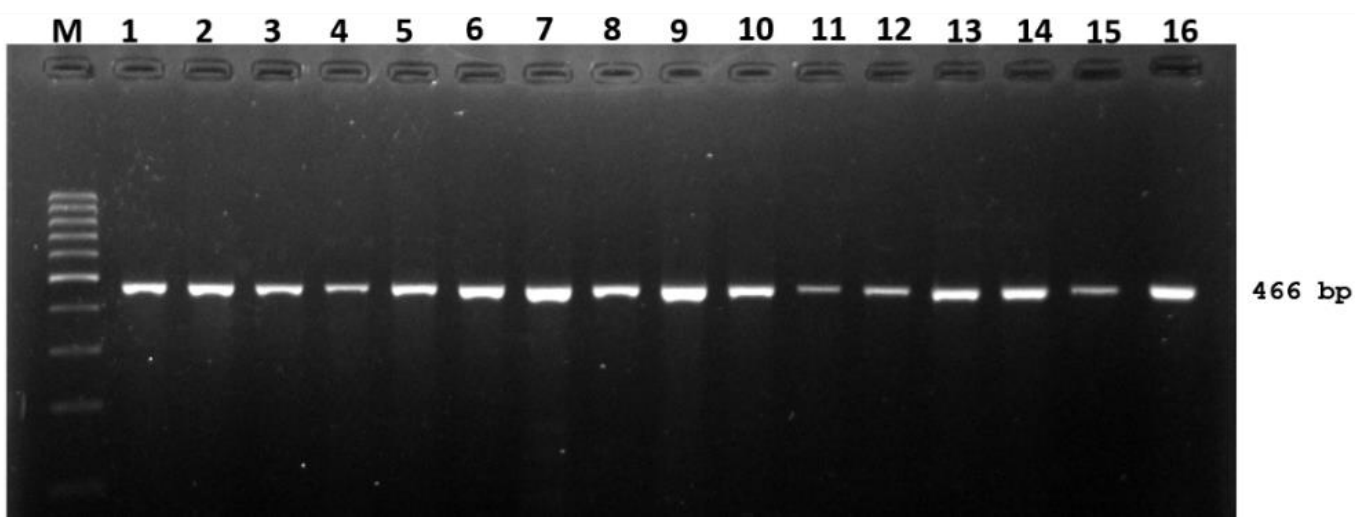

Gambar 1. Hasil amplifikasi gen DGAT dengan panjang 466 bp. $M=$ Marker 100 bp; $1-16=$ sampel domba

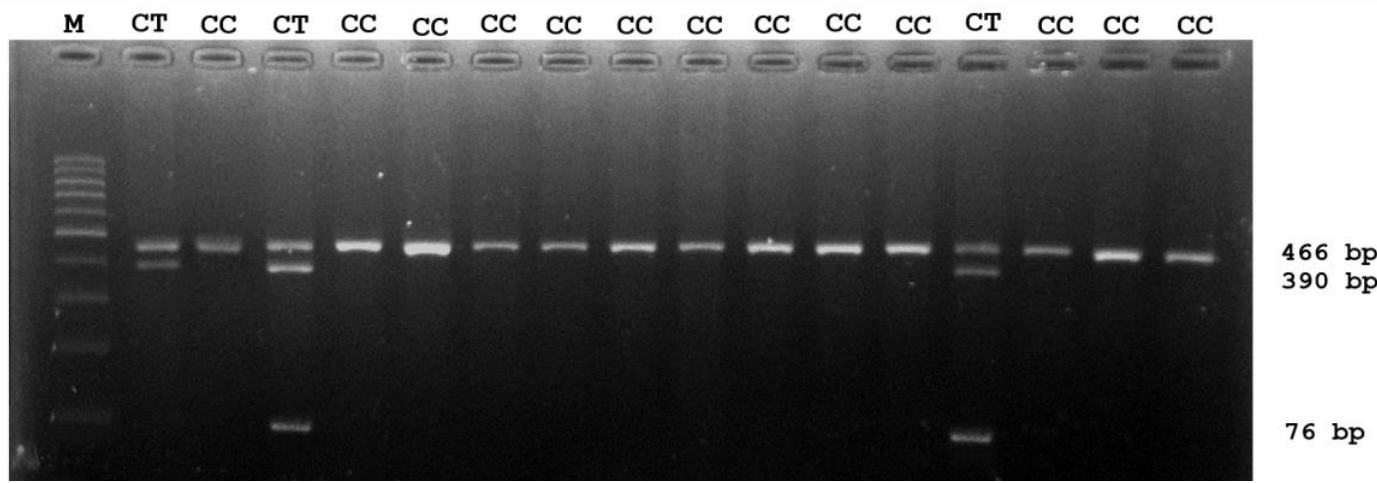

Gambar 2. Hasil PCR-RFLP gen DGAT1 menggunakan enzim AluI. M = Marker 100 bp. Genotipe $\mathrm{CT}=1,3,13$; Genotipe $\mathrm{CC}=2,4-12,14-16$

\section{Genotipe dan Alel Gen DGAT1}

Genotipe yang dihasilkan dari gen DGAT1 terdiri dari dua genotipe yaitu CC dan CT dengan frekuensi masing-masing sebesar 0,90 dan 0,10 untuk DEG dan 0,94 dan 0,06 untuk DET, sedangkan DCA, DBC, dan DKG nilai frekuensi nya 1.00 untuk genotipe CC (Tabel 1). Frekuensi alel C dan T pada DEG, yaitu 0,95 dan 0,05 , sedangkan pada DET 0,97 alel C dan 0,03 alel T (Tabel 1). Frekuensi genotipe dan alel yang diperoleh pada DEG dan DET menunjukkan bahwa gen DGAT1 bersifat polimorfik, sedangkan pada DCA, DBC, dan DKG bersifat monomorfik. Nilai frekuensi alel dan genotipe sama atau kurang dari 0.99 menunjukkan terjadi keragaman dalam populasi (Gunawan et al., 2017). Populasi domba yang digunakan dalam penelitian ini tidak berada dalam keseimbangan HardyWeinberg. Hal ini ditandai dengan hampir semua populasi bersifat monomorfik kecuali pada DEG dan DET. Keseimbangan dalam suatu populasi diartikan bahwa individu dalam populasi belum mengalami seleksi, mutasi, migrasi, dan genetic drift (Noor, 2010).

Tabel 1. Frekuensi genotipe, frekuensi alel, dan keseimbangan Hardy-Weinberg

\begin{tabular}{|c|c|c|c|c|c|c|c|}
\hline \multirow{2}{*}{$\begin{array}{l}\text { Ternak } \\
\text { Domba }\end{array}$} & \multirow{2}{*}{$\mathrm{N}$} & \multicolumn{3}{|c|}{ Frekuensi Genotipe } & \multicolumn{2}{|c|}{ Frekuensi Alel } & \multirow{2}{*}{$\chi^{2}$} \\
\hline & & $\mathrm{CC}$ & $\mathrm{CT}$ & TT & $\mathrm{C}$ & $\mathrm{T}$ & \\
\hline DCA & 35 & $1,00(35)$ & $0,00(0)$ & $0,00(0)$ & 1,00 & 0,00 & - \\
\hline $\mathrm{DBC}$ & 36 & $1,00(36)$ & $0,00(0)$ & $0,00(0)$ & 1,00 & 0,00 & - \\
\hline DKG & 41 & $1,00(41)$ & $0,00(0)$ & $0,00(0)$ & 1,00 & 0,00 & - \\
\hline DEG & 20 & $0,90(18)$ & $0,10(2)$ & $0,00(0)$ & 0,95 & 0,05 & 1,16 \\
\hline DET & 18 & $0,94(17)$ & $0,06(1)$ & $0,00(0)$ & 0,97 & 0,03 & 0,43 \\
\hline Gabungan & 150 & $0,98(147)$ & $0,02(3)$ & $0,00(0)$ & 0,99 & 0,01 & 1,54 \\
\hline
\end{tabular}




\section{Karakteristik Karkas Domba Berdasarkan Genotipe Gen DGAT1}

Asosasi gen DGAT1 dengan karakteristik karkas menunjukkan adanya hubungan yang signifikan $(\mathrm{P}<0.05)$ antara gen DGAT1 dengan karakteristik karkas, diantaranya bobot dan panjang karkas (Tabel 2). Domba dengan genotipe CT memiliki bobot potong dan bobot karkas yang lebih tinggi dibandingkan genotipe $\mathrm{CC}$, namun genotipe $\mathrm{CC}$ memiliki panjang karkas yang lebih tinggi dibandingkan genotipe CT (Tabel 2). Bobot potong dalam penelitian ini berkorelasi positif dengan bobot karkas. Semakin meningkat bobot potong maka bobot karkas akan semakin tinggi. Akantetapi, panjang karkas dalam penelitian ini memiliki korelasi negatif dengan bobot karkas yang dihasilkan. Berbeda dengan penelitian Cloete et al. (2004) yang menunjukkan semakin panjang karkas domba maka bobot karkas nya pun akan semakin tinggi. Selain itu, faktor lain yang memengaruhi karakteristik karkas diantaranya umur, breed, dan jenis kelamin. Peningkatan umur domba menyebabkan ukuran tubuh akan semakin besar sehingga bobot karkas akan semakin tinggi. Domba dengan jenis kelamin jantan memiliki bobot dan panjang karkas yang lebih tinggi dibandingkan betina (Cloete et al., 2004).

Tabel 2. Karakteristik karkas domba berdasarkan genotipe gen DGAT1

\begin{tabular}{lrlcr}
\hline \multirow{2}{*}{ Parameter } & \multirow{2}{*}{$\mathrm{N}$} & \multicolumn{3}{c}{ Genotipe } \\
\cline { 3 - 5 } & & \multicolumn{1}{c}{$\mathrm{CC}(\mathrm{n}=51)$} & $\mathrm{CT}(\mathrm{n}=2)$ & $\mathrm{TT}(\mathrm{n}=0)$ \\
\hline Bobot potong $(\mathrm{kg})$ & 53 & $17.49 \pm 6.45$ & $20.56 \pm 9.27$ & $0.00 \pm 0.00$ \\
Bobot karkas $(\mathrm{kg})$ & 53 & $9.51 \pm 3.36^{\mathrm{b}}$ & $14.12 \pm 0.60^{\mathrm{a}}$ & $0.00 \pm 0.00$ \\
Panjang karkas (cm) & 53 & $84.15 \pm 17.15^{\mathrm{a}}$ & $69.75 \pm 0.35^{\mathrm{b}}$ & $0.00 \pm 0.00$ \\
\hline $\mathrm{N}$ : banyak sampel; $($.$) - banyak$
\end{tabular}

$\mathrm{N}$ : banyak sampel; (..) = banyak sampel yang bergenotipe CC, CT, dan TT

\section{Sifat Perlemakan Domba Berdasarkan Genotipe Gen DGAT1}

Gen DGAT1 secara signifikan $(\mathrm{P}<0.05)$ berhubungan dengan sifat perlemakan diantaranya dengan asam lemak jenuh; asam stearat (C18:0) dan arakidat (C20:0) serta asam lemak tak jenuh tunggal (MUFA), yaitu asam oleat (C18:1n9c). Genotipe CT pada gen DGAT1 menghasilkan domba dengan kandungan asam lemak jenuh stearat (C18:0) dan arakidat (C20:0) lebih rendah dibandingkan dengan genotipe CC. Genotipe CT juga berasosiasi pada tingginya kandungan asam lemak tak jenuh oleat (C18:1n9c). Asam stearat (C18:0) merupakan salah satu komponen asam lemak jenuh. Konsumsi daging yang tinggi kandungan asam lemak jenuh menyebabkan peningkatan kolesterol plasma yang berimplikasi pada penyakit kardiovaskuler (Alvarenga et al., 2015). Namun, konsumsi asam stearat (C18:0) memiliki efek netral dalam tubuh sehingga tidak akan meningkatkan konsentrasi kolesterol LDL (low density lipoprotein) dan hiperkolesterolamia (Grundy, 1994).

Total MUFA (33.26 \pm 0.81$)$ yang paling dominan dalam penelitian ini, yaitu asam oleat $(\mathrm{C} 18: 1 \mathrm{n} 9 \mathrm{c})$ sebesar $30.72 \pm 1.00 \%$ yang dihasilkan oleh genotipe CT, sedangkan genotipe CC menghasilkan nilai asam oleat sebesar $25.51 \pm 5.72 \%$. Gunawan et al. $\left(2018^{\mathrm{b}}\right)$ menyatakan bahwa asam oleat $(\mathrm{C} 18: 1 \mathrm{n} 9 \mathrm{c})$ termasuk kedalam asam lemak tak jenuh tunggal (MUFA) yang paling banyak ditemukan dalam otot. Asam oleat (C18:1n9c) dibentuk oleh asam stearoil oleh aktivitas stearoil CoA desaturase (Wood et al., 2008). Tingkat asam oleat dalam darah dan jaringan lebih banyak dipengaruhi oleh metabolisme endogen dibandingkan asupan makanan. Konsumsi asam oleat (C18:1n9c) dapat menurunkan kadar kolesterol LDL dan meningkatkan HDL (high density lipoprotein) (Khomsan 2004). Menurut Legowo (1996) kolesterol HDL mengandung protein dalam jumlah besar dan kolesterol dalam jumlah kecil sehingga sering disebut kolesterol baik. Asam lemak oleat (C18:1n9c) memiliki peranan penting dalam peningkatan karakteristik daging, keempukan, dan palatabilitas daging (Smith et al., 2009). Murray et al. (2009) menunjukkan bahwa DGAT1 memiliki peranan dalam sintesis trigliserida. Fungsi DGAT1 terletak di dalam struktur protein dan residu asam amino dianggap penting untuk aktivitas enzimatik (Cao, 2011). Gen DGAT1 mengkodekan enzim katalis dari reaksi antara diacylgliserol dan acyl-CoA. Tingkat aktivitas DGAT1 memiliki pengaruh dalam kuantitas deposisi triacylgliserol dalam pembentukan jaringan asam lemak. Hal ini menunjukkan bahwa gen DGAT1 berperan penting dalam sintesis asam lemak. Domba dengan kandungan asam lemak tak jenuh tinggi terutama asam oleat dapat dihasilkan melalui seleksi domba yang memiliki genotipe CT. 
Tabel 3. Sifat perlemakan domba berdasarkan genotipe gen DGAT1

\begin{tabular}{|c|c|c|c|}
\hline \multirow[b]{2}{*}{ Peubah } & \multicolumn{3}{|c|}{ Genotipe DGAT1 } \\
\hline & $\begin{array}{c}\mathrm{CC}(65) \\
(\%)\end{array}$ & $\begin{array}{c}\text { CT (3) } \\
(\%)\end{array}$ & $\begin{array}{c}\mathrm{TT}(0) \\
(\%)\end{array}$ \\
\hline Konten lemak (FC) & $4.01 \pm 3.70$ & $8.78 \pm 4.47$ & $0.00 \pm 0.00$ \\
\hline Asam lemak jenuh (SFA) & $38.65 \pm 8.10$ & $39.92 \pm 6.27$ & $0.00 \pm 0.00$ \\
\hline Asam kaprat (C10:0) & $0.07 \pm 0.04$ & $0.14 \pm 0.10$ & $0.00 \pm 0.00$ \\
\hline Asam laurat (C12:0) & $0.46 \pm 0.54$ & $0.64 \pm 0.56$ & $0.00 \pm 0.00$ \\
\hline Asam miristat (C14:0) & $3.02 \pm 1.85$ & $5.08 \pm 2.76$ & $0.00 \pm 0.00$ \\
\hline Asam pentadekonoat (C15:0) & $0.48 \pm 0.15$ & $0.48 \pm 0.15$ & $0.00 \pm 0.00$ \\
\hline Asam palmitat (C16:0) & $17.57 \pm 3.86$ & $22.02 \pm 1.77$ & $0.00 \pm 0.00$ \\
\hline Asam heptadekanoat (C17:0) & $0.96 \pm 0.37$ & $1.05 \pm 0.27$ & $0.00 \pm 0.00$ \\
\hline Asam stearat (C18:0) & $15.72 \pm 5.97^{\mathrm{a}}$ & $10.44 \pm 1.57^{\mathrm{b}}$ & $0.00 \pm 0.00$ \\
\hline Asam arakidat $(\mathrm{C} 20: 0)$ & $0.11 \pm 0.11^{\mathrm{a}}$ & $0.05 \pm 0.02^{\mathrm{b}}$ & $0.00 \pm 0.00$ \\
\hline Asam lemak tidak jenuh (Unsaturated) & $32.39 \pm 5.09^{b}$ & $35.60 \pm 1.85^{\mathrm{a}}$ & $0.00 \pm 0.00$ \\
\hline Asam lemak tidak jenuh tunggal (MUFA) & $27.82 \pm 6.01$ & $33.26 \pm 0.81$ & $0.00 \pm 0.00$ \\
\hline Asam miristoleinat (C14:1) & $0.15 \pm 0.11$ & $0.19 \pm 0.05$ & $0.00 \pm 0.00$ \\
\hline Asam palmitoleat (C16:1) & $1.63 \pm 1 . .33$ & $1.94 \pm 0.05$ & $0.00 \pm 0.00$ \\
\hline Asam ginkgoleat (C17:1) & $0.48 \pm 0.32$ & $0.40 \pm 0.36$ & $0.00 \pm 0.00$ \\
\hline Asam oleat $(\mathrm{C} 18: 1 \mathrm{n} 9 \mathrm{c})$ & $25.51 \pm 5.72^{\mathrm{b}}$ & $30.72 \pm 1.00^{\mathrm{a}}$ & $0.00 \pm 0.00$ \\
\hline Asam lemak tidak jenuh ganda (PUFA) & 4.57 \pm 3.00 & $2.34 \pm 1.16$ & $0.00 \pm 0.00$ \\
\hline Asam linoleat (C18:2n6c) & $2.75 \pm 1.31$ & $0.11 \pm 0.10$ & $0.00 \pm 0.00$ \\
\hline Asam linolenat (C18:3n3) & $0.22 \pm 0.20$ & $0.12 \pm 012$ & $0.00 \pm 0.00$ \\
\hline Asam arakidonat $(\mathrm{C} 20: 4 \mathrm{n} 6)$ & $1.21 \pm 1.54$ & $0.26 \pm 026$ & $0.00 \pm 0.00$ \\
\hline Asam Eikosapentanoat (C20:5n3) & $0.13 \pm 0.20$ & $0.03 \pm 0.06$ & $0.00 \pm 0.00$ \\
\hline Total asam lemak & $71.06 \pm 9.06$ & $75.65 \pm 7.15$ & $0.00 \pm 0.00$ \\
\hline
\end{tabular}

Angka disertai huruf berbeda pada baris yang sama menunjukkan berbeda nyata $(\mathrm{P}<0.05)$ pada taraf $\alpha=0.05$

\section{KESIMPULAN}

Keragaman gen DGAT1|Alul (g.8539 C $>$ T) berhasil diidentifikasi pada DEG dan DET dengan dua genotipe, yaitu CC dan CT. Perbedaan genotipe gen DGAT1 memiliki pengaruh yang signifikan $(\mathrm{P}<0.05)$ terhadap karakteristik karkas, yaitu bobot dan panjang karkas, serta berpengaruh signifikan pada sifat perlemakan yaitu komposisi asam lemak diantaranya asam lemak jenuh, yaitu asam stearat (C18:0) dan asam arakidat (C20:0) dan asam lemak tak jenuh tunggal, yaitu asam oleat (C18:1n9c). Domba dengan genotipe CT menghasilkan karakteristik karkas yang lebih besar dan memiliki kandungan lemak tak jenuh (MUFA) yaitu asam oleat (C18:1n9c) yang lebih tinggi dibandingkan domba genotipe CC. SNP g.8539 C>T gen DGAT1 memiliki potensi sebagai penanda genetik untuk seleksi domba dengan kualitas daging domba bermutu tinggi yaitu bobot dan panjang karkas besar serta kandungan asam lemak tak jenuh tinggi.

\section{UCAPAN TERIMA KASIH}

Ucapan terima kasih kepada Kementrian Pertanian yang telah membiayai penelitian ini melalui Projek Penelitian KP4S dengan Nomor Kontrak: 76.60/PL.040/H.1/04/2017.K date 20 April 2017.

\section{DAFTAR PUSTAKA}

AOAC. 2012. Official Methods of Analysis of the Association of Official Analytical Chemist. Washington, Arlington, USA.

Alwiyah. 2016. Identifikasi keragaman gen DGAT1 dan SCD serta asosiasinya terhadap kualitas karkas pada sapi bali. Tesis. Sekolah Pascasarjana. Institut Pertanian Bogor. Bogor.

Alvarenga, T.I.R.C., Y. Chen, I.F. FurushoGarcia, \& J.R.O. Perez. 2015. Manipulation of omega-3 PUFAs in lamb:phenotypic and genotypic views. Comprehensive Reviews in Food Science and Food Safety 14:189-204.

Casses, S., S.J. Smith, Y.W. Zheng, H.M. Myers, S.R. Lear \& E. Sande. 1998. Identification 
of a gene encoding an acyl CoA diacylglycerol acyltransferase, a key enzyme in triacylglycerol synthesis. Proc. Natl Acad Sci. United States of America, 1998 0ct 27th. p 13018-13023.

Cao, J., Y. Zhou, H. Peng, X. Huang, S. Stahler, V. Suri, A. Qadri, T. Gareski, J. Jones, S. Hahm, M. Perreault, J. McKew, M. Shil, X. Xu, J.F. Tobin, \& R.E. Gimeno. 2011. Targeting acyl-coa:diacylglycerol acyltransferase 1 (DGAT1) with small molecule inhibitors for the treatment of metabolic diseases. J. Biol Chem. p 2-3.

Cloete, J.J.E., L.C. Hoffman, S.W.P. Cloete, \& J.E. Fourie. 2004. A comparison between the body composition, carcass characteristics, and retail cuts of south african mutton merino and dormer sheep. J. Anim. Sci. 34 (1):44-51.

DPKH. 2017. Statistik Peternakan dan Kesehatan Hewan. Direktorat Jenderal Peternakan dan Kesehatan. Jakarta.

Folch, J., M. Lee, \& G. Sloae-Stanley. 1957. A simple method for the isolation and purification of total lipids from animal tissues. J. Biol. Chem. 226:497-509.

Grisart, B., W. Coppieters, F. Farnir, L. Karim, C. Ford, P. Berzi, N. Cambisano, M. Mni, S. Reid, P. Simon, R. Spelman, M. Georges, \& R. Snell. 2002. Positional candidate cloning of a QTL in dairy cattle: identification of a missense mutation in the bovine DGAT1 gene with major effect on milk yield and composition. Genome Resc. 12:222-231.

Grundy, S.M. 1994. Influece of stearic acid on cholesterol metabolism relative to other long-chain fatty acid. Am J Clin Nutr. 60: 986-990.

Gunawan, A., C. Sumantri, \& R. Juniarti. 2017. Gen dan Keragaman Genetik Ternak. IPB Press. Bogor.

Gunawan, A., F. W. Pramukti, K. Listyarini, M.A.M. Abuzahra, Jakaria, C. Sumantri, I. Inounu, \& M.J. Uddin. 2019. Novel variant in the leptin receptor (LEPR) gene and its association with fat quality, odour, and flavour in sheep. JITAA 44 (1):1-9

Gunawan, A., Jakaria, K. Listyarini, A. Furqon, C. Sumantri, S. H. Akter, \& M. J. Uddin. 2018a. Transcriptome signature of liver tissue with divergent mutton odour and flavour using RNA deep sequencing. Gene. 676(2018):86-94

Gunawan, A., D. Anggrela, K. Listyarini, M.A.M. Abuzahra, Jakaria, M. Yamin, I. Inounu, \& C. Sumantri. 2018b. Identification of single nucleotide polymorphism and pathway analysis of apolipoprotein A5 (APOA5) related to fatty acid traits in sheep. Trop. Anim. Sci. J. 43 (3):165-173

Gunawan, A., S. Tazkya, K. Listyarini, M. Yamin, I. Inounu, \& C. Sumantri. 2018c. Karakterisasi Gen KIF12 (Kinesin Familly 12) serta Hubungannya dengan Komposisi Asam Lemak pada Domba. Jurnal Ilmu dan Teknologi Peternakan Tropis. 5(3):88-94

Hidayati. 2015. Single nucleotide polymorphisme of lipoprotein lipase gene and its association with marbling quality in local sheep. Trop. Anim. Sci. J. 40(1): $1-10$.

Inounu, K., N. Shoji, T. Honda, \& K. Oyama. 2017. Genetic relationship between meat quality traits and fatty acid composition in Japanese black cattle. Anim. Sci. J. 88: $11-18$.

Khomsan, A. 2004. Peranan Pangan dan Gizi untuk Kualitas Hidup. PT Gramedia. Jakarta.

Klug, W.S., M. R. Cummings, \& C.A. Spencer. 2006. Concepts of Genetics Ed-8. Pearson Prentice Hall. New Jersey.

Legowo, A.M. 1996. Masalah Lemak dan Kolesterol dalam Bahan Pangan Hewani. Media. Edisi Tri Tahun XXI. Juni 1996. HIm 8-15.

Listyarini, K., Jakaria, M. J. Uddin, C. Sumantri, \& A. Gunawan. 2018. Association and expression of CYP2A6 and KIF12 genes related to lamb flavour and odour. Trop. Anim. Sci. J. 41(2):100-107

Mohammadi, H., M.M. Shahrebabak, \& M. Sadeghi. 2013. Association between single nucleotide polymorphism in the ovine gene and carcass traits in two Iranian sheep breeds. Anim Biotech. 24: 159-167. 
Muladno. 2009. Teknologi Rekayasa Genetika. IPB Press. Bogor.

Noor, R.R. 2010. Genetika Ternak. Penebar Swadaya. Jakarta.

OECD. 2017. Meat consumption. https://data.oecd.org/agroutput/meatconsumption.htm. (20 November 2018).

Sambrook, J., E.F. Fritsch, \& J.F. Medrano. 1989. Molecular Cloning: a Laboratory Manual Ed-2. Cold Spring Harbor Laboratory Pr. New York

Smith, S.B., C.A. Gill, D.K. Lunt, \& M.A. Brooks. 2009. Regulation of fat and fatty acid composition in beef cattle. Asian. Aus. J. Anim. Sci. 22(9):1225-1233.

Taniguchi, M., T. Utsugi, K. Oyama, H. Mannen, M. Kobayashi, Y. Tanabe, A. Ogino \& S. Tsuji. 2004. Genotype of stearoyl-CoA desaturase is 22 associated with fatty acid composition in Japanese Black cattle. Mamm Genome. 14:142148.

Walpole, R. 1995. Pengantar Statistika. PT Gramedia Pustaka Utama. Jakarta.

Wood, J.D., M. Enser, A.V. Fisher, G.R. Nute, P.R. Sheard, R.I. Richardson, S.I. Hughes \& F.M. Whittington. 2008. Fat deposition, fatty acid composition, and meat quality [review]. Meat Sci. 78:343-358.

Xu, Q.L., Y.L. Chen, R.X. Ma \& P. Xue. 2008. Polymorphism of DGAT1 associated with intramuscular fat-mediated tenderness in sheep. J. of The Sci. of Food. and Agric. 89(2):232-237. 